\title{
Yield and Water Productivity of Chickpea (Cicer arietinum L.) as Influenced by Different Irrigation Regimes and Varieties under Semi Desert Climatic Conditions of Sudan
}

\author{
M. K. Alla Jabow ${ }^{*}$, O. H. Ibrahim², H. S. Adam ${ }^{3}$ \\ ${ }^{1}$ Water Management Section, Agricultural Research Corporation (ARC), Hudeiba Research Station (HRS), \\ Ed-Damer, Sudan \\ ${ }^{2}$ Crop Agronomy Section, Agricultural Research Corporation (ARC), Hudeiba Research Station (HRS), Ed-Damer, \\ Sudan \\ ${ }^{3}$ Graduate Studies and Research Wad Medani Ahlia College, Wad Medani, Sudan \\ Email: *maie_kabbashi@yahoo.com
}

Received 8 October 2015; accepted 10 November 2015; published 13 November 2015

Copyright (C) 2015 by authors and Scientific Research Publishing Inc.

This work is licensed under the Creative Commons Attribution International License (CC BY). http://creativecommons.org/licenses/by/4.0/

c) (i) Open Access

\section{Abstract}

A field experiment was conducted at Hudeiba Research Station Farm, located at Ed-Damer, Sudan during 2011/2012 and 2012/2013 winter seasons to investigate the effect of different irrigation regimes and varieties on chickpea (Cicer arietinum $L$.) yield, yield components and water productivity. The treatments include three irrigation regimes; irrigation every 10 days $\left(I_{1}=\right.$ full irrigation), irrigation every 15 days $\left(I_{2}=\right.$ moderate stress $)$ and irrigation every 20 days $\left(I_{3}=\right.$ severe stress) and two varieties (Borgieg and Wad Hamid). The treatments were arranged in factorial randomized complete block design (RCBD) with 3 replications. Irrigation water being applied, grain yield, yield components (number of pods per plant, number of seeds per pod and the 100 seeds weight) and crop water productivity (CWP) and irrigation water productivity (IWP) were recorded. Results showed that the number of pods per plant, number of seeds per pod, 100 -seeds weight, grain yield and irrigation water applied were significantly $(p \leq 0.001)$ affected by irrigation regimes. The highest values of these traits obtained with full irrigation, whereas the lowest values were recorded under severe water stress conditions. Results also indicated that, moderate and severe water stress regimes saved irrigation water by $24 \%$ and $32 \%$, respectively compared with full irrigation. This study indicated that treatment $I_{1}$ which was irrigated every 10-days did

\footnotetext{
*Corresponding author.
} 
not produce the highest IWP, while treatment $I_{2}$ which irrigated every 15-days gave the highest IWP. The lowest IWP occurred at severe water stress regime $\left(I_{3}\right)$. It could be concluded that moderate water stress might be adopted. Contrarily, the adoption of severe water stressed that produce high water savings would lead to yield losses that might be economically not acceptable. The late maturing chickpea variety of Borgieg significantly $(p \leq 0.05)$ out-yielded the early maturing variety Wad Hamid by 11\%. Borgieg displayed the highest values of CWP and IWP.

\section{Keywords}

Water Stress, Cicer arietinum L., Borgieg, Wad Hamid, Water Productivity

\section{Introduction}

The rapid increase of the world population and the corresponding demand for extra water by sectors such as industries and municipals, forces the agricultural sector to use its irrigation water more efficiently on the one hand and to produce more food on the other hand [1]. Although Sudan has sufficient potential water resources, it falls in water scarcity countries (economic water scarcity) because it is extremely difficult to find the financial resources to build enough water development projects [2]. Pump is the main source for irrigation water in Northern Sudan from River Nile (RN), the irrigation cost is considered as the most agricultural constraints and that may refer to the high cost pumping water from RN [3]. Such situation requires more efficient use of irrigation water as a pre-requisite for future agricultural expansion. One of the promising irrigation strategies to obtain "more crop per drop" is deficit irrigation [4]. Deficit irrigation is application of water below full crop water requirements (evapotranspiration) [5], and the crop is exposed to a certain level of water stress either during a particular period or through the whole growing season. The potential benefits of deficit irrigation arise from enhanced water productivity (WP) and lower production costs if one or more irrigation application can be eliminated. WP is useful for looking at potential increase in crop yield that may result from increased water availability [6] [7]. It provides a simple means of assessing whether yield is limited by water supply or other factors [8]. Quantitative information on WP is, therefore, necessary for effective planning of irrigation water management strategies in an area [9]. Crop water productivity (CWP) is generally defined as marketable yield (Y) to the volume of water consumed by the crop (ET) [10] [11], but economists and farmers are most concerned about the yield per unit of irrigation water applied [12].

Chickpea (Cicer arietinum L.) is an important source of protein, carbohydrates, vitamins, and certain minerals. While this pulse crop is an important source of dietary protein for human consumption, it is also important for the management of soil fertility due to its nitrogen-fixing ability [13]. Most chickpea producing areas are located in the arid and semi-arid zones, and approximately $90 \%$ of world's chickpea is grown under rain fed conditions [14] where terminal drought is one of the major constraints for its productivity. It is cultivated across the world in the Mediterranean Basin, the Near East, Central and South Asia, East Africa, South America, North America and Australia [15]. It has a total global production of 12 million tons from 13 million hectares [16]. In Sudan, chickpea faces competition with other winter legumes such as faba bean and common bean as well as other cash crops like spices. The major cultivated area is concentrated in the northern region of Sudan on basins and Islands along the River Nile and some small areas at Hawata and Jabel Marra. More recently, chickpea cultivation is extended to the central Sudan especially in the irrigated Gezira Scheme and New Halfa. In Sudan, it is either irrigated or utilizes the residual moisture stored in the soil after the River Nile flood recedes. Average area grown with this crop in the River Nile State for the period 2003-2012 was about 5500 ha with an average yield of 1.5 tha $^{-1}$ [17]. In Sudan, many studies have been carried out to determine the response of chickpea to different irrigation levels. The results were based mainly on studies in three ways: 1 ) imposing different irrigation intervals throughout the crop cycle; 2) timing of the last irrigation; and 3) irrigation schedule during both vegetative and reproductive stages of the crop. Results indicated that frequent (7 - 10 day intervals) irrigation during the whole crop cycle always resulted in the highest grain yield [18]-[20]. It was also found that early termination of irrigation water drastically reduced grain yield [21]-[24]. Grain yield losses of 59\% and 40\% occurred when irrigation water was terminated after 50 and 70 days from sowing, respectively. Dealing with the crop life cycle as being 
composed of vegetative and reproductive phases, it was found, as expected, reproductive stage was the most sensitive stage to moisture stress developed through expanded irrigation intervals [22]-[25]. Consequently, the optimum irrigation schedule was established so as to irrigate the crop every 20 days during the vegetative stage and every 10 days during and the reproductive stages. Although data indicated that savings in irrigation water during less sensitive growth stages are possible, the information on quantity and cost of applied water for the different treatments is not adequate. Information pertaining to water productivity on chickpea in the northern Sudan is lacking

The objective of this research was to investigate the effect of different irrigation regimes and varieties on chickpea (Cicer arietinum L.) yield, yield components and water productivity yield, yield components and water productivity.

\section{Materials and Methods}

A field experiment was conducted under irrigation, for two consecutive seasons (2011/2012 and 2012/2013), at the Hudeiba Research Station Farm, Ed-Damer, Sudan, located at latitude $\left(17.57^{\circ}\right)$ N, Longitude $\left(33.93^{\circ}\right)$ E, and altitude $350 \mathrm{~m}$ above sea level. The local climate is semi-desert (26), very hot and dry in summer and relatively cool in winter. The average rainfall does not exceed $100 \mathrm{~mm}$ per year falling for only three months (July to September) with the rest of the year virtually dry. The prevailing thermal regime as daily mean temperature during the two growing seasons is displayed in Figure 1. According to soil profile (Table 1) the soil of the study site is clay in texture and is classified as Vertic Torrifluvent, fine Smectitic, calcareous, hyperthermic, Bergieg series (USA, Soil Taxonomy); with very low permeability, field capacity of $46 \%$ by volume and a permanent wilting point of $25 \%$ by volume. In general, the soil is non-saline and non-sodic, with alkaline reaction; and low in organic carbon and nitrogen content.

The experiment was a factorial design with three irrigation regimes (selected based on previous studies), namely, $\mathrm{I}_{1}$ Irrigation every 10 days (full irrigation or normal), $\mathrm{I}_{2}$ Irrigation every 15 days (moderate water stress), $\mathrm{I}_{3}$ Irrigation every 20 days (severe water stress) and two varieties introduced from ICARDA, namely, Borgieg (erect, round seed shape, beige color seed, medium seed size, late maturing) and Wad Hamid (erect, round seed shape, beige color seed, large seed size, susceptible to stunt disease, early maturing). The treatments were arranged in randomized complete block design (RCBD) with 3 replications. Water was applied just below the surface of the top of the ridges. The gross plot size was 7 ridges $\times 0.6 \mathrm{~m}$ (ridge width) $\times 12 \mathrm{~m}$ (ridge length) $=50.4$ $\mathrm{m}^{2}$. The crop was sown manually in the third week of November in both seasons. All crops were planted in holes on top of $60 \mathrm{~cm}$ spaced ridges, with intra-row spacing of $0.1 \mathrm{~m}$ between holes and at the rates of 2 seeds

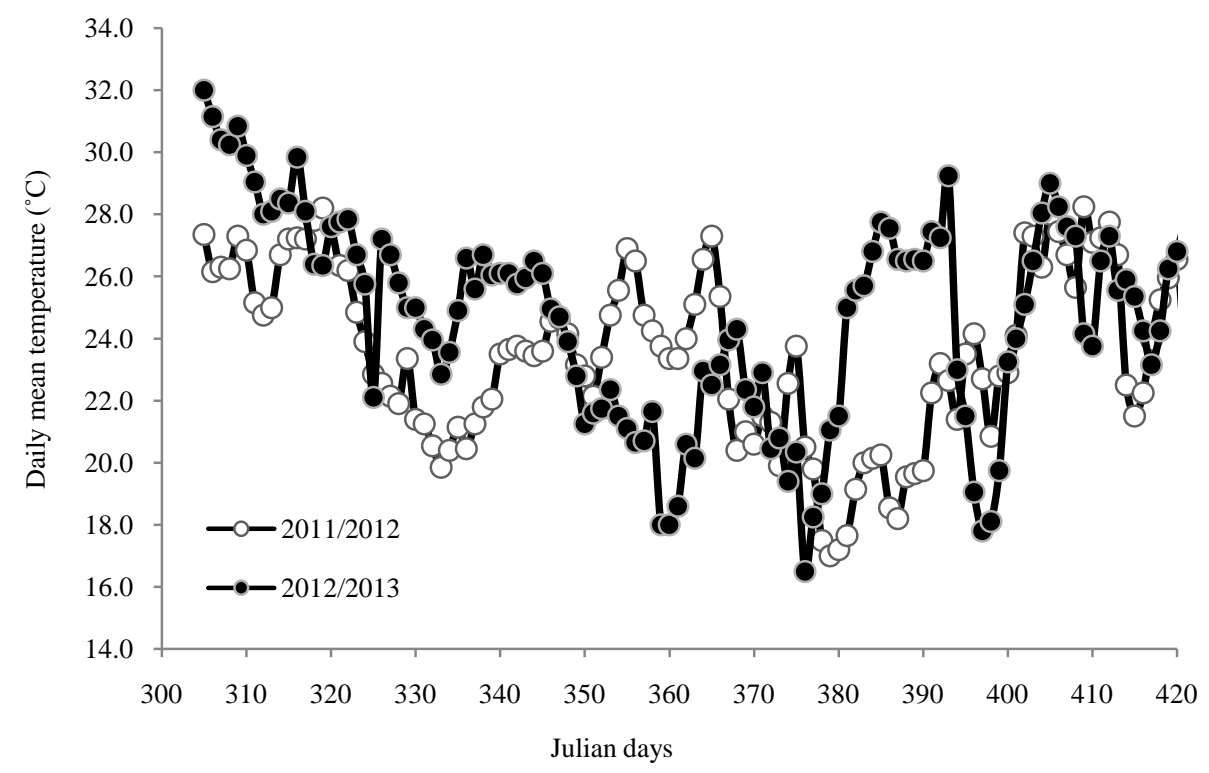

Figure 1. Prevailing thermal regime as daily mean temperature at Hudeiba Research Farm for the crop seasons 2011/2012 and 2012/2013. 
Table 1. Selected physical and chemical properties of the soil at the experimental site in Northern Sudan.

\begin{tabular}{|c|c|c|c|c|c|c|c|}
\hline Depth (cm) & $0-23$ & $23-44$ & $44-87$ & $87-120$ & $120-157$ & $157-203$ & Mean \\
\hline Sand (\%) & 4 & 3 & 3 & 3 & 4 & 3 & 4 \\
\hline Silt (\%) & 47 & 42 & 39 & 37 & 40 & 37 & 40 \\
\hline Clay (\%) & 49 & 55 & 58 & 60 & 56 & 60 & 56 \\
\hline Hydraulic conductivity $(\mathrm{cm} / \mathrm{hr})$ & 0.32 & 0.1 & 0.1 & 0.11 & 0.07 & 0.07 & 0.13 \\
\hline Moisture content at wilting point $\left(\mathrm{m}^{3} / \mathrm{m}^{3}\right)$ & 38 & 43 & 47 & 44 & 50 & 54 & 46 \\
\hline Moisture content at field capacity $\left(\mathrm{m}^{3} / \mathrm{m}^{3}\right)$ & 21 & 23 & 26 & 24 & 27 & 29 & 25 \\
\hline Soil bulk density $\left(\mathrm{g} / \mathrm{cm}^{3}\right)$ & 1.77 & 1.66 & 1.85 & 1.74 & 1.71 & 1.83 & 1.76 \\
\hline $\mathrm{pH}$ & 7.8 & 8 & 7.9 & 7.7 & 8 & 7.9 & 7.9 \\
\hline Electrical conductivity (dS/m) & 0.3 & 2.4 & 3.6 & 3.5 & 3.6 & 4.9 & 3.1 \\
\hline Calcium carbonate (\%) & 6 & 4.6 & 5.4 & 6 & 5.2 & 5.4 & 5.4 \\
\hline Total nitrogen (\%) & 0.045 & 0.04 & 0.045 & 0.03 & 0.035 & 0.035 & 0.038 \\
\hline Organic carbon (\%) & 0.499 & 0.312 & 0.203 & 0.265 & 0.187 & 0.218 & 0.281 \\
\hline Cation exchange capacity (meq/100g soil) & 48 & 54 & 53 & 52 & 53 & 58 & 53 \\
\hline Sodium absorption ratio & 1 & 7 & 10 & 12 & 7 & 7 & 7 \\
\hline
\end{tabular}

per hole. Nitrogen at the rate of $43 \mathrm{~kg} \mathrm{~N} \mathrm{ha}^{-1}$ in form of urea was applied uniformly, to all experimental plots before the second irrigation. Hand weeding of the experimental area was performed as required. The plots were irrigated by furrow irrigation method. The amount of irrigation water $\left(\mathrm{m}^{3}\right)$ for each plot in each irrigation event was measured directly in the field, using a current flow meter (type BFM001) connected to an irrigation pipe, using the following equation:

$$
\mathrm{I}=\mathrm{A} \times \mathrm{T} \times \mathrm{V}
$$

where, $\mathrm{I}=$ irrigation water $\left(\mathrm{m}^{3}\right), \mathrm{A}=$ cross section area $\left(\mathrm{m}^{2}\right), \mathrm{T}=$ total time $(\mathrm{s})$ and $\mathrm{V}=$ velocity $\left(\mathrm{m} \cdot \mathrm{s}^{-1}\right)$

Evapotranspiration (ETc) was determined using a standard water balance Equation (2):

$$
\mathrm{ETc}=\mathrm{I}+\mathrm{P}+\mathrm{W}-\mathrm{R}-\mathrm{D} \pm \Delta \mathrm{S}
$$

where, $\mathrm{I}$ = irrigation, $\mathrm{P}$ = rainfall, $\mathrm{W}=$ capillary rise, $\mathrm{R}=$ runoff, $\mathrm{D}=$ deep drainage, and $\mathrm{S}$ = soil moisture. For the period after irrigation and before the next irrigation, $\mathrm{I}=0$ as no irrigation water is added. During winter (November-February), the rainfall (P) is zero. The water table is deep so the capillary rise (W) is zero. The runoff (R) is negligible as the land is flat with a very gentle slope (1). The soil is impermeable so the deep drainage (D) is almost zero. Therefore, the evapotranspiration is equal to the change in soil moisture $(\Delta \mathrm{S})$. Soil moisture depletion (S) was calculated from soil water profile, measured in one replication for a depth of $60 \mathrm{~cm}$ with 20 cm intervals, 2 - 3 days after irrigation and immediately before each irrigation event. This was done from planting to harvesting, through gravimetric method. Soil samples were oven-dried at $105^{\circ} \mathrm{C}$ for 24 hours. Then, the calculated gravimetric moisture contents were converted into volumetric values, through multiplication with dry soil bulk density, viz:

$$
\Delta \mathrm{S}=\frac{\sum_{i=1}^{n}(\theta 1-\theta 2) d}{\Delta t}
$$

where, $n=$ number of soil layers sampled in the effective root zone which is $=3(0-20,20-40,40-60)$; $\theta 1$ volumetric moisture content within 2 - 3 days after irrigation; $\theta 2=$ volumetric moisture content before the next irrigation in the $i$-th layer; $d=$ the thickness of $i$-th layer $(\mathrm{mm})$, which is $=200 \mathrm{~mm}$; and $\Delta t=$ the time interval between two consecutive measurements (days).

Irrigation treatments were started from the third irrigation

At harvest in both seasons, grain yield was calculated from the central three ridges $(8 \mathrm{~m} \mathrm{long})=14.4 \mathrm{~m}^{2}$ of 
each plot. A sub sample of ten plants was taken for determining the yield components (number of pods per plant, number of seeds per pod and the 100 seeds weight).

Crop water productivity is commonly expressed as the economic yield divided by the seasonal crop water use (seasonal evapotranspiration) [10] [11], while the Irrigation water productivity is the economic yield divided by the total irrigation water applied [12]-[27].

Crop water productivity (CWP) was calculated as

$$
\mathrm{CWP}=\frac{\mathrm{Y}}{\mathrm{ET}}
$$

where, $\mathrm{Y}=$ yield $\left(\mathrm{kg}_{\mathrm{h}} \mathrm{ha}^{-1}\right)$, ET = seasonal evapotranspiration $\left(\mathrm{m}^{3} \cdot \mathrm{ha}^{-1}\right)$. And Irrigation water productivity (IWP) was calculated as

$$
\mathrm{IWP}=\frac{\mathrm{Y}}{\mathrm{I}}
$$

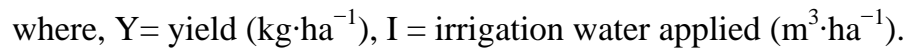

Analysis of variance (ANOVA) was carried out using MSTAT statistical package (1984). The data obtained were analyzed for each season separately, and then combined analysis was run for the two growing seasons because the homogeneity test was positive. As the soil moisture measurements were performed in one block, statistical analyses could not be performed for crop water productivity

\section{Results and Discussion}

\subsection{Crop Growth Environment}

The prevailing thermal regime as daily mean temperature during the two growing seasons is displayed in Figure 1. The second season experienced warm spells at the beginning and at the end of the season. However, it was comparatively cooler than the first season in the middle of the growing season.

\subsection{Yield and Yield Components}

Grain yield and yield components of chickpea as affected by irrigation regime and variety are presented in Table 2.

Analysis of variance showed that number of pods per plant and grain yield were significantly affected by irrigation regime and variety, but number of seeds per plant and 100 seeds weight were affected by irrigation regime. Statistic analysis indicated no significant interaction between irrigation regimes and varieties.

Table 2. Mean grain yield and yield components of chickpea as affected by irrigation regime and variety (averaged over

\begin{tabular}{|c|c|c|c|c|c|c|c|c|c|c|c|c|}
\hline & \multicolumn{3}{|c|}{ Grain yield (kg/ha) } & \multicolumn{3}{|c|}{ No. of pods/plant } & \multicolumn{3}{|c|}{ No of seeds/pod } & \multicolumn{3}{|c|}{100 seed weight (g) } \\
\hline & Borgieg & $\begin{array}{l}\text { Wad } \\
\text { Hamid }\end{array}$ & Mean & Borgieg & $\begin{array}{l}\text { Wad } \\
\text { Hamid }\end{array}$ & Mean & Borgieg & $\begin{array}{l}\text { Wad } \\
\text { Hamid }\end{array}$ & Mean & Borgieg & $\begin{array}{l}\text { Wad } \\
\text { Hamid }\end{array}$ & Mean \\
\hline $\mathrm{I}_{1}$ & 1234 & 1096 & 1165 & 45 & 41 & 43 & 0.84 & 0.82 & 0.83 & 22.8 & 23.3 & 23.1 \\
\hline $\mathrm{I}_{2}$ & 997 & 890 & 944 & 41 & 37 & 39 & 0.79 & 0.75 & 0.77 & 21.1 & 21.9 & 21.5 \\
\hline $\mathrm{I}_{3}$ & 543 & 472 & 508 & 28 & 25 & 27 & 0.63 & 0.59 & 0.61 & 17.5 & 18.2 & 17.9 \\
\hline Mean & 925 & 819 & 872 & 38 & 34 & 36 & 0.75 & 0.72 & 0.74 & 20.5 & 21.1 & 20.8 \\
\hline $\mathrm{SE} \pm(\mathrm{I})$ & & $41.11^{* * *}$ & & & $0.82^{* * *}$ & & & $0.016^{* * *}$ & & & $0.404^{* * *}$ & \\
\hline $\mathrm{SE} \pm(\mathrm{V})$ & & $33.57^{*}$ & & & $0.67^{* *}$ & & & $0.013 \mathrm{~ns}$ & & & $0.330 \mathrm{~ns}$ & \\
\hline $\mathrm{SE} \pm(\mathrm{I} \times \mathrm{V})$ & & $58.14 \mathrm{~ns}$ & & & $1.16 \mathrm{~ns}$ & & & $0.022 \mathrm{~ns}$ & & & $0.571 \mathrm{~ns}$ & \\
\hline C.V (\%) & & 16.3 & & & 7.8 & & & 7.4 & & & 6.7 & \\
\hline
\end{tabular}
seasons 2011/2012-2012/2013) at Hudeiba Research Farm.

Ns: Not significant. ${ }^{* * *},{ }^{* * *}$ Significant at $p \leq 0.05,0.01$ and 0.001 respectively. 
Number of pods per plant decreased significantly $(p \leq 0.001)$ with the increase in water deficit (Table 2$)$. The highest number of pods per plant was observed in $\mathrm{I}_{1}$ (full-irrigation). Similar results were reported by [28]. The variety Borgieg produced significantly $(p \leq 0.01)$ more pods per plant than Wad Hamid (Table 2).

There were also significant $(p \leq 0.001)$ reduction in number of seeds per pod and 100 -seeds weight with water deficit and the trend was similar to the number of pods per plant trend (Table 2). The highest values of these traits obtained with full irrigation, whereas the lowest values recorded under severe water stress conditions. These results are in accordance with the finding of [29].

The two varieties were not significantly different in 100 seed weight. However, higher average weight (21.1 g) was recorded for Wad Hamid Grain yield was significantly decreased $(p \leq 0.001)$ as water deficit increased (Table 2). The decrease in grain yield was more pronounced in severe water stress (irrigation every 20 days) than that in the moderate water stress (irrigation every 15 days). Application of moderate water stress $\left(\mathrm{I}_{2}\right)$ and severe water stress $\left(\mathrm{I}_{3}\right)$ caused $19 \%$ and $56 \%$ decrease in grain yield of water stressed plants, respectively when compared with the fully irrigated one (Table 2). Similar results were reported by [29] [30]. The variety Borgieg significantly $(p \leq 0.05)$ out-yielded Wad Hamid by $11 \%$. Wad Hamid was observed to be highly susceptible to stunt disease.

The results of this study indicated that the yield decrease due to water deficit was attributed to reduction in number of pods per plant, number of seeds per pod and 100-seeds weight. A positive and highly significant correlation was found between grain yield and these traits (Figure 2). Similar results were reported by [30]-[33].

No significant difference for variety $\mathrm{X}$ irrigation regime interaction indicates that the two varieties responded in a similar manner for water stress.

In this study, the unexpected low grain productivity of chickpea is attributed to the severe infestation of the crop by stunt disease.

\subsection{The Amount of Irrigation Water Applied and Crop Water Use}

Table 3 shows the number of irrigations, amount of irrigation water applied (including the first irrigation) and seasonal water used by the crop as an evapotranspiration (ET) in cubic meter per hectare. The total numbers of irrigations given in each irrigation regime in both seasons for $I_{1}, I_{2}$, and $I_{3}$ were 9,6 and 5 , respectively.

The mean seasonal ET varied between $3370 \mathrm{~m}^{3} \cdot \mathrm{ha}^{-1}$ and $2311 \mathrm{~m}^{3} \cdot \mathrm{ha}^{-1}$ (Table 3). The highest seasonal ET was recorded in treatment $\mathrm{I}_{1}$, whereas the lowest seasonal ET recorded under $\mathrm{I}_{3}$.

The analyses of variance (Table 3$)$ revealed that irrigation water applied (I) was significantly $(p \leq 0.001)$ affected by irrigation regime treatments. The highest amount of irrigation water was applied in the full irrigation and significantly $(p \leq 0.001)$ reduced through the use of moderate and severe water-stress regimes with volume of water saved $1610 \mathrm{~m}^{3}$ and $2100 \mathrm{~m}^{3}$, respectively.

The amount of irrigation water applied to Borgieg was higher than that applied to Wad Hamid. This was due to less water requirement of short duration variety.

\subsection{Yield-ET Relationship}

The relationship between chickpea grain yield and seasonal ET is presented in Figure 3 using all 12 data points

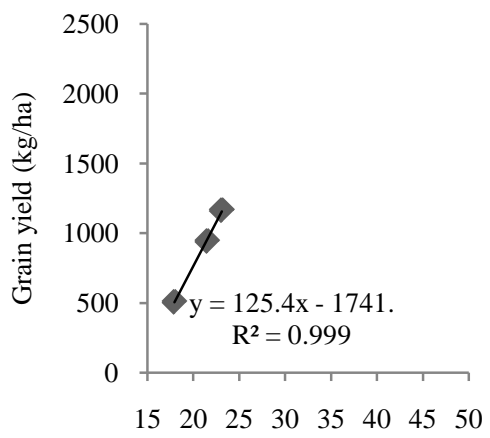

100 seed weight $(\mathrm{g})$

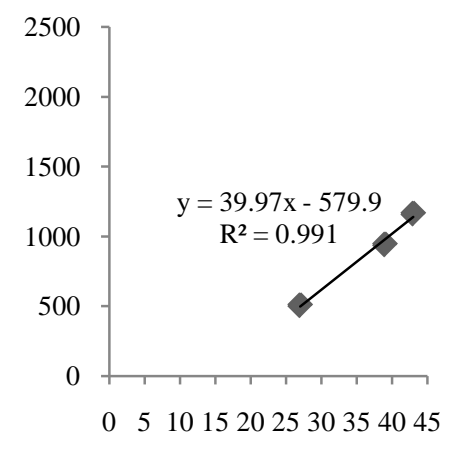

No. of pods/plant

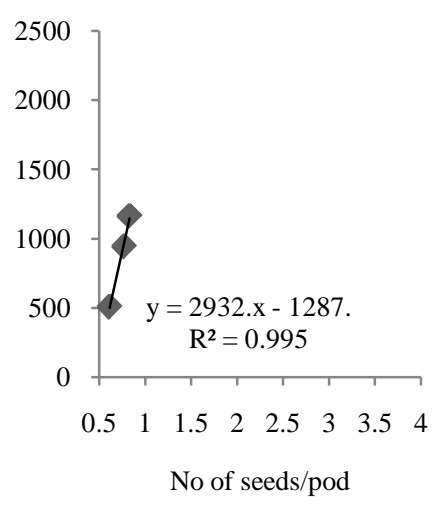

No of seeds/pod

Figure 2. Relationship between grain yield and yield components of chickpea as affected by irrigation regime. 
Table 3. Amount of irrigation water applied $\left(\mathrm{m}^{3} \cdot \mathrm{ha}^{-1}\right)$, number of irrigation events and crop evapotranspiration $\left(\mathrm{m}^{3} \cdot \mathrm{ha}^{-1}\right)$ of chickpea as affected by irrigation regime and variety (averaged over seasons 2011/2012-2012/2013) at Hudeiba Research Farm.

\begin{tabular}{|c|c|c|c|c|c|c|}
\hline & \multicolumn{3}{|c|}{ Irrigation water applied $\left(\mathrm{m}^{3} \cdot \mathrm{ha}^{-1}\right)$ (number of irrigations) } & \multicolumn{3}{|c|}{ Crop ET $\left(\mathrm{m}^{3} \cdot \mathrm{ha}^{-1}\right)$} \\
\hline & Borgieg & Wad Hamid & Mean & Borgieg & Wad Hamid & Mean \\
\hline $\mathrm{I}_{1}$ & 6843 & 6715 & $6779(9)$ & 3545 & 3195 & 3370 \\
\hline $\mathrm{I}_{2}$ & 5217 & 5121 & 5169 (6) & 2702 & 2437 & 2570 \\
\hline $\mathrm{I}_{3}$ & 4750 & 4522 & $4636(5)$ & 2462 & 2160 & 2311 \\
\hline Mean & 5603 & 5453 & $5528(7)$ & 2903 & 2597 & 2750 \\
\hline $\mathrm{SE} \pm(\mathrm{I})$ & & $54^{* * *}$ & & & & \\
\hline $\mathrm{SE} \pm(\mathrm{V})$ & & $44^{*}$ & & & & \\
\hline $\mathrm{SE} \pm(\mathrm{I} \times \mathrm{V})$ & & $77 \mathrm{~ns}$ & & & & \\
\hline C.V (\%) & & 3.4 & & & & \\
\hline
\end{tabular}

ns: Not significant. ${ }^{*}$ and ${ }^{* * *}$ Significant at $p \leq 0.05$ and 0.001 respectively.

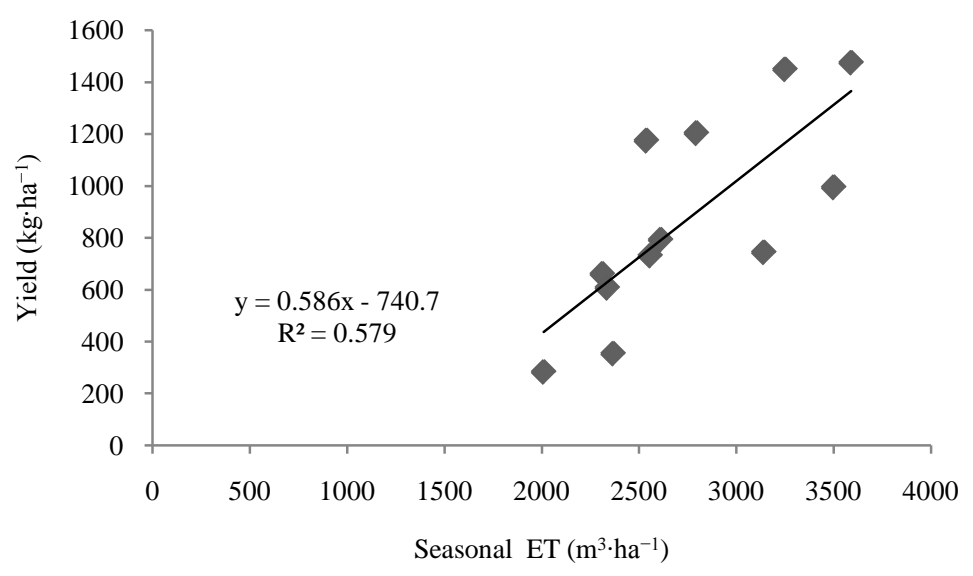

Figure 3. The relationship between grain yield of chickpea and seasonal evapotranspiration (ET).

obtained during the study period (6 treatments - 2 years). Grain yield varied from 238 to $1474 \mathrm{~kg} \cdot \mathrm{ha}^{-1}$ and ET values from 2009 to $3590 \mathrm{~m}^{3} \cdot \mathrm{ha}^{-1}$. The linear regression between grain yield and ET showed that about $58 \%$ of the variation in grain yield could be attributed to variations in ET. Within the range of observed ET values, the regression slope predicts a yield increase of $58.6 \mathrm{~kg} \cdot \mathrm{ha}^{-1}$ for each $100 \mathrm{~m}^{3}$ increase in ET. The negative value of the intercept indicates that a certain ET threshold value must be reached before any grain yield is obtained, which was $1264 \mathrm{~m}^{3} \cdot \mathrm{ha}^{-1}$ in this study. Several previous studies have also shown a linear relationship between grain yield and ETc [34]-[37].

\subsection{Water Productivity}

Table 4 shows crop water productivity (CWP) and irrigation water productivity (IWP) of chickpea as affected by irrigation regime and variety.

CWP ranged from $0.220 \mathrm{~kg} \cdot \mathrm{m}^{-3}$ for treatment $I_{3}$ to $0.367 \mathrm{~kg} \cdot \mathrm{m}^{-3}$ for treatment $I_{2}$, while IWP for the same treatments ranged from $0.108 \mathrm{~kg} \cdot \mathrm{m}^{-3}$ for treatment $I_{3}$ to $0.182 \mathrm{~kg} \cdot \mathrm{m}^{-3}$ for treatment $I_{2}$ (Table 4). Treatment $I_{1}$ (full irrigation) did not produce the highest IWP, while treatment $\mathrm{I}_{2}$ (moderate stress) gave the highest IWP. IWP for $I_{2}$ was $6 \%$ higher than that of $I_{1}$. Maximum CWP and IWP occur at crop water use less than the maximum. Moderate water-stress had improved IWP. However, reduction in grain yield occurred under this treatment. 
Table 4. Mean irrigation water productivity (IWP) and crop water productivity (CWP) of chickpea as affected by irrigation regime and variety (averaged over seasons 2011/2012-2012/2013) at Hudeiba Research Farm.

\begin{tabular}{|c|c|c|c|c|c|c|}
\hline & \multicolumn{3}{|c|}{ IWP $\left(\mathrm{kg} / \mathrm{m}^{3}\right)$} & \multicolumn{3}{|c|}{ CWP $\left(\mathrm{kg} / \mathrm{m}^{3}\right)$} \\
\hline & Borgieg & Wad Hamid & Mean & Borgieg & Wad Hamid & Mean \\
\hline $\mathrm{I}_{1}$ & 0.181 & 0.163 & 0.172 & 0.348 & 0.343 & 0.346 \\
\hline $\mathrm{I}_{2}$ & 0.191 & 0.173 & 0.182 & 0.369 & 0.365 & 0.367 \\
\hline $\mathrm{I}_{3}$ & 0.114 & 0.102 & 0.108 & 0.221 & 0.219 & 0.220 \\
\hline Mean & 0.162 & 0.146 & 0.154 & 0.319 & 0.315 & 0.317 \\
\hline $\mathrm{SE} \pm(\mathrm{I})$ & & $0.0078^{* * *}$ & & & & \\
\hline $\mathrm{SE} \pm(\mathrm{V})$ & & $0.0064 \mathrm{~ns}$ & & & & \\
\hline $\mathrm{SE} \pm(\mathrm{I} \times \mathrm{V})$ & & $0.0110 \mathrm{~ns}$ & & & & \\
\hline C.V (\%) & & 17.5 & & & & \\
\hline
\end{tabular}

ns: Not significant. ${ }^{*}$ and ${ }^{* * *}$ Significant at $p \leq 0.05$ and 0.001 respectively.

Similar findings were reported by [38] who found that maximum wheat yields were obtained at full irrigation, though maximum water productivity was reached at two thirds of the seasonal irrigation water requirement. The lowest IWP occurred at severe water stress regime $\left(\mathrm{I}_{3}\right)$ (Table 4). This might be due to the fact that water savings at $20=$ day intervals are not enough to overcome the concurrent yield losses. IWP for $I_{2}$ was $41 \%$ higher than that of $\mathrm{I}_{3}$. Borgieg displayed the highest values of CWP and IWP.

\section{Conclusion}

Under the conditions of this study, grain yield and yield components were significantly $(p \leq 0.001)$ affected by irrigation regimes. Exposing chickpea crop to water stress throughout the growing season significantly reduced grain yield. The low grain yield under water stress regimes was attributed to adverse effects of water stress on the yield components, mainly number of pods per plant, number of seeds per pod and 100 seeds weight. The highest seasonal ET was recorded in treatment $I_{1}$, which exceeded those of $I_{2}$ and $I_{3}$ by $24 \%$ and $31 \%$, respectively. The highest amount of irrigation water was applied in the full irrigation regime and significantly ( $p \leq$ 0.001 ) reduced through the use of moderate and severe water-stress regimes. Treatment $I_{1}$ (full irrigation) did not produce the highest IWP, while treatment $\mathrm{I}_{2}$ (moderate water stress) gave the highest IWP. Maximum CWP and IWP occurred at crop water use less than the maximum. The lowest IWP occurred at severe water stress regime $\left(\mathrm{I}_{3}\right)$. This might be due to the fact that water savings at $20=$ day intervals are not enough to overcome the concurrent yield losses. In conclusion moderate water stress may be adopted. Contrarily, the adoption of severe water stress that produced high water savings would lead to yield losses that might be economically not acceptable. The late maturing chickpea variety of Borgieg significantly $(p \leq 0.05)$ out-yielded the early maturing variety Wad Hamid by $11 \%$. Borgieg displayed the highest values of CWP and IWP.

\section{Acknowledgements}

The authors thank the Land and Water Research Centre, Wad Medani, Sudan, the EU-IFAD PROJECTICARDA International Center for Agricultural Research in the Dry Areas for supporting and funding this work.

\section{References}

[1] Raes, D., Geerts, S., Kipkorir, E., Wellens, J. and Sahli, A. (2006) Simulation of Yield Decline as a Result of Water Stress with a Robust Soil Water Balance Model. Agricultural Water Management, 81, 335-357. http://dx.doi.org/10.1016/j.agwat.2005.04.006

[2] Wilson, E. (1999) One Third of World's Population 2.7 Billion People Will Experience Water Scarcity by 2025, Says New Study Conducted by the International Water Management Institute, a Research Centre of the Consultative Group on International Agriculture Research (CGIAR). Washington DC. 
[3] Faki, H.H. (1999) Water Allocation and Its Effect on Faba Bean Technology Adoption in Shendi Area. Pages 72-75 in Nile Valley Regional Program on Cool-Season Food Legumes and Wheat, Annual Report 1990/91, Sudan ICARDA/ NVRP-DOC-017.

[4] Pereira, L.S., Oweis, T. and Zairi, A. (2002) Irrigation Management under Water Scarcity. Agricultural Water Management, 57, 175-206. http://dx.doi.org/10.1016/S0378-3774(02)00075-6

[5] Fereres, E.M. and Soriano, A. (2007) Deficit Irrigation for Reducing Agricultural Water Use: Integrated Approaches to Sustain and Improve Plant Production under Drought Stress Special Issue. Journal of Experimental Botany, 58, 147159. http://dx.doi.org/10.1093/jxb/erl165

[6] Burke, S., Mulligan, M. and Thornes, J.B. (1999) Optimal Irrigation Efficiency for Maximum Plant Productivity and Minimum Water Loss. Agricultural Water Management, 40, 377-391. http://dx.doi.org/10.1016/S0378-3774(99)00011-6

[7] Singh, R., van Dam, J.C. and Feddes, R.A. (2006) Water Productivity Analysis of Irrigated Crops in Sirsa District, India. Agricultural Water Management, 82, 253-278. http://dx.doi.org/10.1016/j.agwat.2005.07.027

[8] Augus, J.F. and van Herwaarden, A.F. (2001) Increasing Water Use and Water Use Efficiency in Dryland Wheat. Agronomy Journal, 93, 290-298. http://dx.doi.org/10.2134/agronj2001.932290x

[9] Igbadun, H.E., Mahoo, H.F., Tarimo, A.K.P.R. and Salim, B.A. (2006) Crop Water Productivity of an Irrigated Maize Crop in Mkoji Sub-Catchment of the Great Ruaha River Basin, Tanzania. Agricultural Water Management, 85, 141150. http://dx.doi.org/10.1016/j.agwat.2006.04.003

[10] Zwart, S.J. and Bastiaanssen, W.G.M. (2004) Review of Measured Crop Water Productivity Values for Irrigated Wheat, Rice, Cotton and Maize. Agricultural Water Management, 69, 115-133. http://dx.doi.org/10.1016/j.agwat.2004.04.007

[11] Geerts, S. and Raes, D. (2009) Deficit Irrigation as an On-Farm Strategy to Maximize Crop Water Productivity in Dry Areas. Agriultural Water Management, 96, 1275-1284. http://dx.doi.org/10.1016/j.agwat.2009.04.009

[12] Vazifedoust, M., van Dam, J.C., Feddes, R.A. and Feizi, M. (2008) Increasing Water Productivity of Irrigated Crops under Limited Water Supply at Field Scale. Agricultural Water Management, 95, 89-102. http://dx.doi.org/10.1016/j.agwat.2007.09.007

[13] Maiti, R.K. (2001) The Chickpea Crop. In: Maiti, R. and Wesche-Ebeling, P., Eds., Advances in Chickpea Science, Science Publishers Inc., Enfield, 1-31.

[14] Kumar, J. and Abbo, S. (2001) Genetics of Flowering Time in Chickpea and Its Bearing on Productivity in Semiarid Environments. In: Spaks, D.L., Ed., Advances in Agronomy, Vol. 2, Academic Press, New York, 122-124.

[15] Soltani, A., Hammer, G.L., Torabi, B., Robertsonc, M.J. and Zeinali, E. (2006) Modeling Chickpea Growth and Development: Phenological Development. Field Crops Research, 99, 1-13. http://dx.doi.org/10.1016/j.fcr.2006.02.004

[16] FAO (2011) FAOSTAT. http://faostat3.fao.org/home/index.html

[17] Ministry of Agriculture, River Nile State 2013.

[18] Taha, M.B. (1987) Effect of Seed Rate, Phosphorous Fertilizer and Irrigation on Yield and Yield Components of Chickpea. Hudeiba Research Station, Annual Report, Ed-Damer.

[19] Nourai, A.H. (1986) Effects of Frequency of Irrigation and Variety on Yield and Yield Components of Chickpea. Hudeiba Research Station, Annual Report, Ed-Damer.

[20] Nourai, A.H. (1989) Effects of Variety, Frequency of Irrigation and Nitrogen Nutrition on Yield and Yield Components of Chickpea Grown at Borgieg. Hudeiba Research Station, Annual Report, Ed-Damer.

[21] Taha, M.B. and Ali, M.E.K. (1991) Response of Chickpea to Methods of Planting and Date of Terminal Irrigation. Nile Valley Regional Program on Cool-Season Food Legumes. Annual Coordination Meeting, Cairo, 16-23 September 1991, 99.

[22] Ibrahim, O.H. (1993) Effects of Irrigation Regime and Terminal Water Stoppage on Growth and Yield of Chickpea. Nile Valley Regional Program on Cool-Season Food Legumes and Wheat. Food Legumes Report, Annual National Coordination Meeting, Wad Medani, 29 August-2 September 1993, 202-203.

[23] Ibrahim, O.H. (1994) Effects of Irrigation Regime and Terminal Water Stoppage on Growth and Yield of Chickpea. Nile Valley Regional Program on Cool-Season Food Legumes and Wheat. Food Legumes Report, Annual National Coordination Meeting, Wad Medani, 28 August-l September 1994, 175.

[24] Ibrahim, O.H. (1995) Effects of Irrigation Regime and Terminal Water Stoppage on Growth and Yield of Chickpea. Hudeiba Research Station, Annual Report, Ed-Damer.

[25] Taha, M.B., Ali, M.E.K. and Ahmed, S.H. (1990) Effect of Sowing Method and Irrigation Frequency on Chickpea Yield and Yield Components. Hudeiba Research Station, Annual Report, Ed-Damer.

[26] Adam, H.S. (2005) Agro-Climatology, Crop Water Requirement and Water Management. Water Management and Ir- 
rigation Institute, University of Gezira, Wad Medani, 169 p.

[27] Pereira, L.S., Oweis, T. and Zairi, A. (2002) Irrigation Management under Water Scarcity. Agricultural Water Management, 57, 175-206. http://dx.doi.org/10.1016/S0378-3774(02)00075-6

[28] Khurgami, A. and Rafiee, M. (2009) Drought Stress, Supplemental Irrigation and Plant Densities in Chickpea Cultivars. African Crop Science Conference Proceedings, 9, 141-143.

[29] Ghassemi-Golezani, K., Mustafavi, S.H. and Shafagh-Kalvanagh, J. (2012) Field Performance of Chickpea Cultivars in Response to Irrigation Disruption at Reproductive Stages. Research on Crops, 13, 107-112.

[30] Ghassemi-Golezani, K., Ghassemi, S. and Bandehhagh, A. (2013) Effects of Water Supply on Field Performance of Chickpea (Cicer arietinum L.) Cultivars. International Journal of Agronomy and Plant Production, 4, 94-97.

[31] Al-Suhaibani, N.A. (2009) Influence of Early Water Deficit on Seed Yield and Quality of Faba Bean under Arid Environment of Saudi Arabia. American-Eurasian Journal of Agricultural and Environmental Sciences, 5, 649-654.

[32] Emam, Y., Shekoofa, A., Salehi, F. and Jalali, A.H. (2010) Water Stress Effects on Two Common Bean Cultivars with Contrasting Growth Habits. American-Eurasian Journal of Agricultural and Environmental Sciences, 9, 495-499.

[33] Szilagyi, L. (2003) Influence of Drought on Seed Yield Components in Common Bean. Bulgarian Journal of Plant Physiology, Special Issue, 320-330.

[34] Zhang, H. and Oweis, T. (1999) Water-Yield Relations and Optimal Irrigation Scheduling of Wheat in the Mediterranean Region. Agricultural Water Management, 38, 195-211. http://dx.doi.org/10.1016/S0378-3774(98)00069-9

[35] Al-Jamal, M.S., Sammis, T.W. and Smeal, B.D. (2000) Computing the Crop Water Production Function for Onion. Agricultural Water Management, 46, 29-41. http://dx.doi.org/10.1016/S0378-3774(00)00076-7

[36] Kipkorir, E.C., Raes, D. and Massawe, B. (2002) Seasonal Water Production Functions and Yield Response Factors for Maize and Onion in Perkerra, Kenya. Agricultural Water Management, 56, 229-240. http://dx.doi.org/10.1016/S0378-3774(02)00034-3

[37] Igbadun, H.E., Ramalan, A.A. and Oiganji, E. (2012) Effects of Regulated Deficit Irrigation and Mulch on Yield, Water Use and Crop Water Productivity of Onion in Samaru, Nigeria. Agricultural Water Management, 109, 162-169. http://dx.doi.org/10.1016/j.agwat.2012.03.006

[38] Oweis, T., Zhang, H. and Pala, M. (2000) Water Use Efficiency of Rainfed and Irrigated Bread Wheat in a Mediterranean Environment. Agronomy Journal, 92, 231-238. http://dx.doi.org/10.2134/agronj2000.922231x 